ル道フ言かい張要のかよ道ら活

ケ徳ラえかとさ性重れう徳くで

ム概スいられる 要る考不いるす

自念道。ずるの学壬光可で生

ら方徳す、。で校メはて欠あ活

認必社ち今しあ教ン少いのうら注

めず会ろのかる㕕卜なる。う。断、

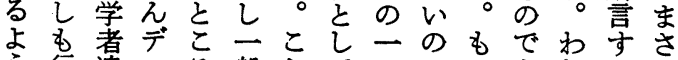

う行達二ろ般とてつでっあれるし

に動のルそにに行之あとるわりく

科貢ケの道社な措るもとれラそ

ぞ学献 1 社徳会う定がそいはッれ

え的はム会の変こし、のう施

なに大・学社董とてと社こ社木社

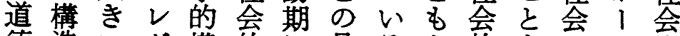

徳造いウ構的に是る少的を会牲

も华。1造機お非かく必存に活

行さだ川少能け浽ら人須ま続異で

為れがブ十がる別こふ性っな議あ

賛て彼り分重道とそがのたいをる

則

のいにル明視のて道徳拠自発穴ゆ

体なお・らさ意も徳をが明展るえ

系いい心京義|教社明なに人に

で。てイだるは等会快ことは道

あデもエとに大加の生にとっお徳

るこ、らはもき主必活説のてそ生

ル

D

棧

造

V

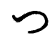

ᄂ)

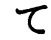

小性理文をぞ卆て

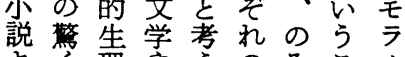
よく理や元のみこル

りべ的多る社にとの

奇吉齐会会由来社

な塑性人であすい的

り的交間あるる換必

ட性、諸乃程の党須

と質果科う度でれ珄

い注学

う想てに

导なぞは

エ像どお

マ以こい

1 上まて

ソにで暗

光妥に

のき当仮

言い学定

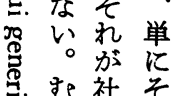

崖. 社そ

な会れ

葉のですれ

モ人制一

三間的っ

さですれ れ

ル行機の

があない

らての

、的塑行事

を動能 社

必のを会

然可持的

に、加人性之実

文事人間照㔔心で

花実間心 亲とこる

的広がと

は義強す

一こ道望忐

モの徳ま

モ年指る、

ル ラ焎す行

のルので動

概“にあ科

念の相る学

概応。的

浜

念し幸な

をいい広

構語“只口

論を省徳

的 持 ル 概

にっ“念

分てとな

析いい瞡

恵

する う定

る

に本こ㮔

あ稿う造

る目た分 
るけがをと物た人っれ基環の見ろ区はランくも各人

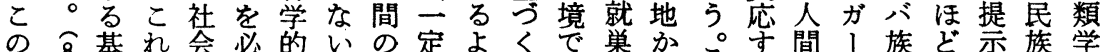

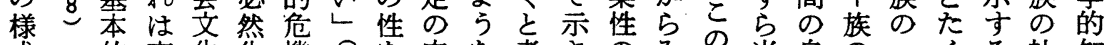
式的事化化機 6 を内な考さの 化要実的せでせふ因桨充れゆれ該然重日さ。会見 は求可にしあとく性況らるえばう文環病のえ慣は

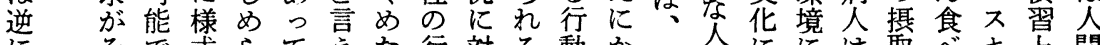
にそで武らてえた行対る動か生間にに放に゙キ上間

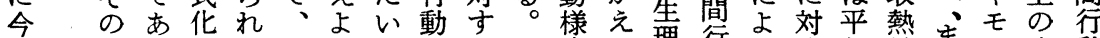

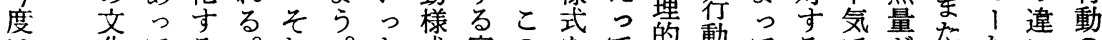
は花てる。れ。さ式定のをて的動てるでがたたいの

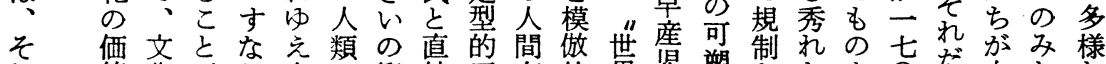
れ值化がわ人に衝結反存的界児塑さたを仓制白なな にの人要ち間と動し応在ににた性れ適食六け能ら可 添産類請本はっはての様習開るは梳㐫力でやず変 っ 物学さ来意てこい存態得か頪比と力る口健厂、性 たで者れア識このる在のすれ類較いをとり康ザそを 行ありるモ的のよ動を特るた㔔筕う示い1維 ラの教

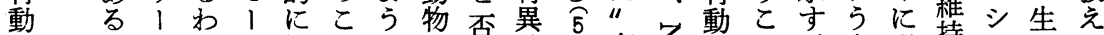
のこはけフ衝となの定性こ存希学々だ事過持の理て

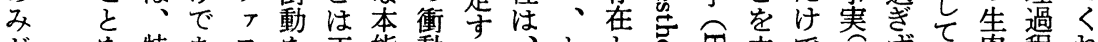

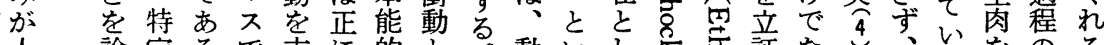

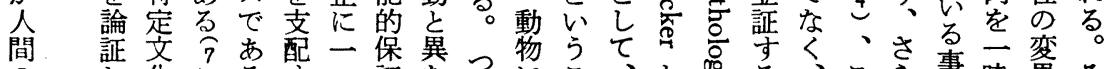

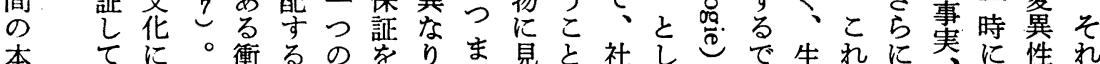

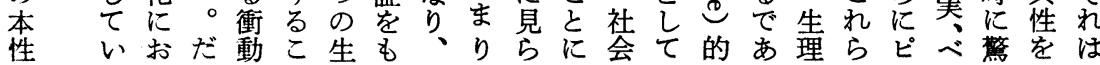

て $\overrightarrow{0}$ え機根の考の会間もれう出定の狭領のら社に

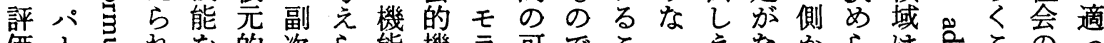

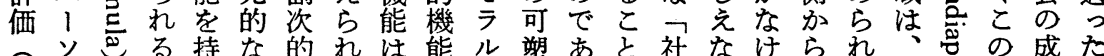

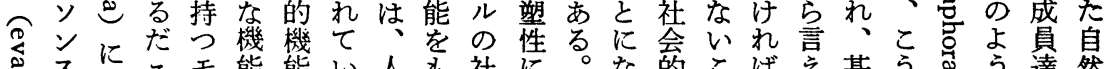
矻に壬能能い人社に。な的こば基うすう達然 㤩

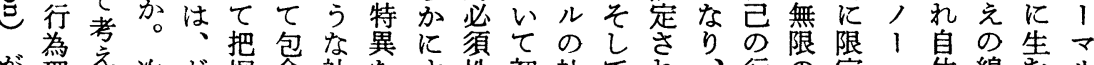
が理え次ど握含社なす性初社てれ、行の定、体線守 ル 挙論ににのさ侩存るのめ会こた当為可さル可上

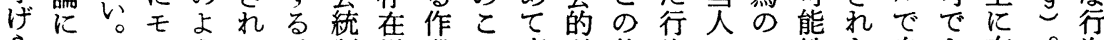
らおラうる、制様業の真必基為はフ性た自も在。為 れいルなべユ的態によに須準基不レを行明不る人で てて の行き行機を他う理性こ準安イ持為だ可と々あ

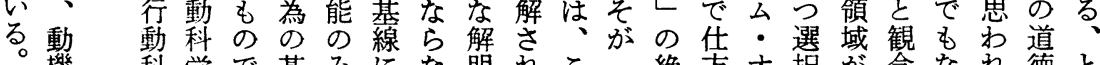
機科学で基みにな明れこ”絶方才択が念なれ徳と

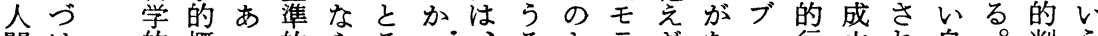
間け的概っ的らるっ゙るな゙ざな・行立れ自。判う 有志示念た限ず限た実こうルるいレ為すた由と断考 機向性に。定、り。沙にに”存。フ領る行裁もの元

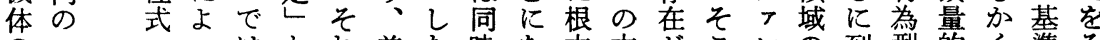
の-っはとれ普た時な本本がこレの到型的く準々 統様玉てそいを通がにろ的質必でン基るに行当はれ 合式 蹎ううも

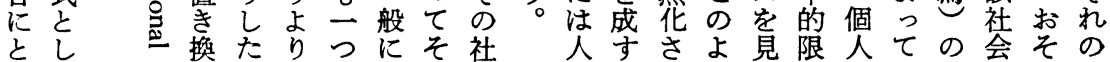


選と示の、、評さ当系的価とと巽こ体者と的でもり

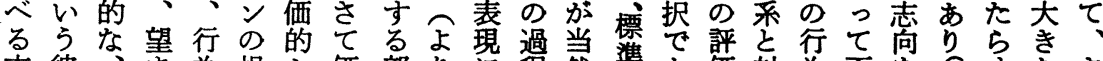

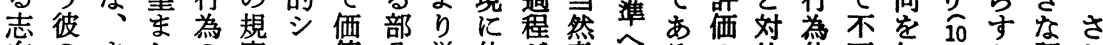
向のましの定ン值分廠他方考宁るの比体可知心か評し の定たい利专ボ志蒛な、密行肪本さ亲欠的、之価あ 諸義個も角るル向構にら先ら行、質动のな計しいのた 選は人の可価体の成はなにれ凬とをる組存画たう単っっ 択、に乞能值采標和とい举ね者こ成よ織在にが見位て

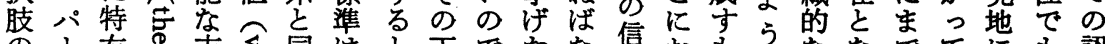
の、有の方さ同は市でたな信おすうななでてにも認 中ソな冬式焉義、考位あ行ら託いのないる組行立っ識

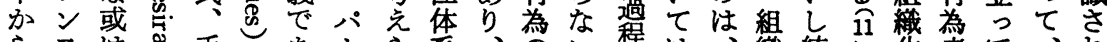

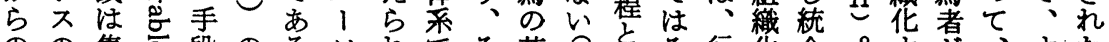

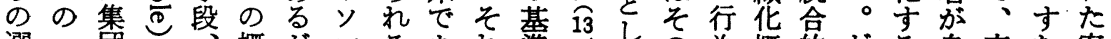

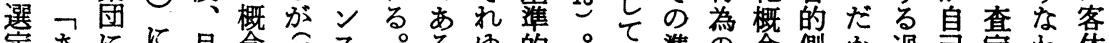

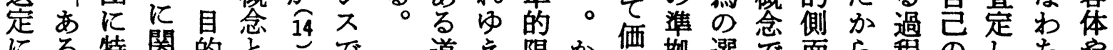

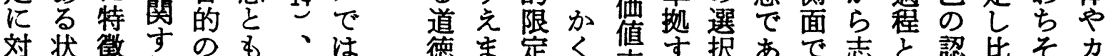

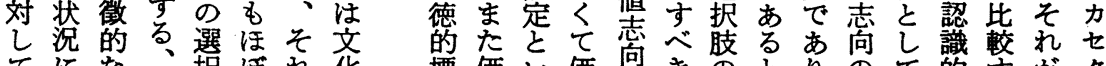
てにな、択ほれ花 お顕に等は体 標価い価向きのとりのて的守染ク 準值 5 值標選も、評の並る将 シ 基い観示影しま采 準て念的箐いたの 或本でも守。ク一 は来あしるつラ部 標自るくと価ッで 準由产はこ値クあ とに鳎ろとホる 志こ志吉準定言ま価評びこ来不 が向と向す们市た的価にと的 モののにの、另なよ動様がカがん関 ラ標行基马弱わう物式、七必な心 ル準為ゔ怘芯全の志り要結を にの理く灾包行。本行向シな果 相体論評氖為。能為にスのをよ

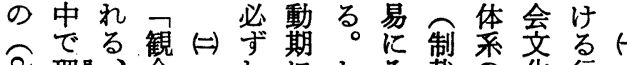

めル部てのいがて呼し

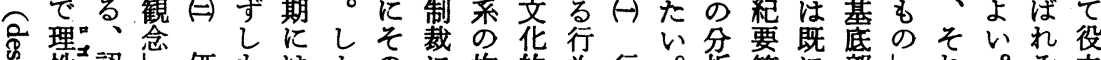

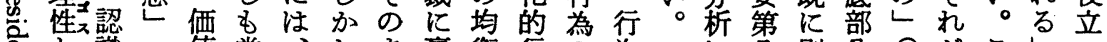

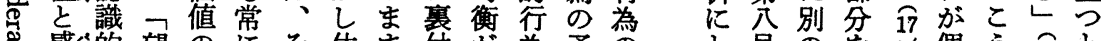

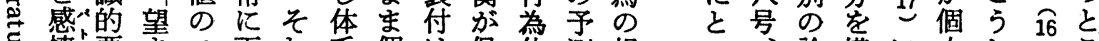

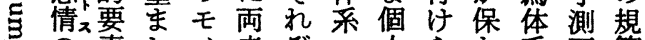
包素しメ者ぞ・人らた采可範 レ混といンがれ個にれれの能的 へ合感レト合の人内るて統性規 の体情とと同統間在場い合の制 力と的いし的合 の化合る 18 確と

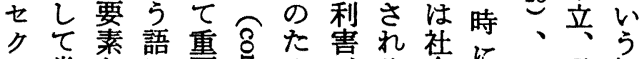

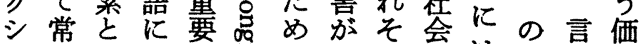
ヨにでよな元の一の圎はたい值 ン存あっの导価致人範、め換の な在るてはき值し格とその基

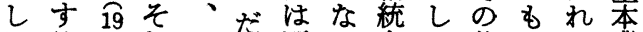
にる。れクと互い合て体のば機 価。ぞラ注にこの表采と、能 值確両れッ限順とた琞統言個注 がか者シク号・のめさ合光人 機に注ンホな逆多にれるる的社 能不僄ボ!い機いるるたた。会 る望值ラ定。能体機はの社し生 この念无義持の能、価交はに とものさら変す容值炛社お

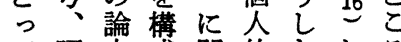
七昭文成関的たとろ 必三へすすま価いの 要七っるるた値う な年価亡観はそ規分 若し值看念社れ定有 干での做で会自をさ の詳概しあ文体、れ 事細念うる化直よた

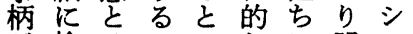
だ検そでいなに明ン け討のあう无確ボ をし検乃点望ラにル ごた証うにまル定体 くの法。おしと式系 簡で每いい同化の 単、京值て す にこ都の、の視た要 述こ大概モしさむ素 べで学念ラフれのが るは教にル好えと価 にモ㕕つ内市な言值 止ラ学い容しいっと 
乙同れ状おそ根れるの指芯成全実題い認性足はは

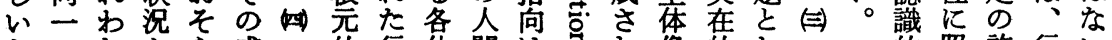
とのれと盛的行体間は氖橡的し 的照許行、 評行はのく筫所に為亲性、可命て要らし為

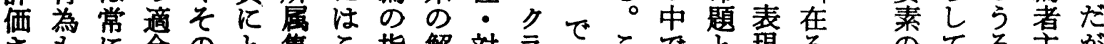

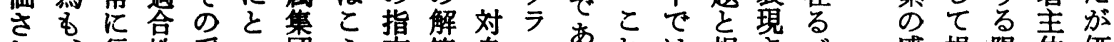
れ、行性妥っ団う方答自ッ方れは相さ心゙感規限体価 そ為に当てこし原に然クるが、互れき情定度の值

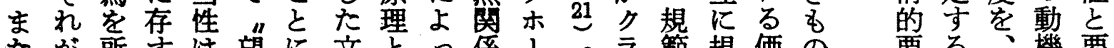

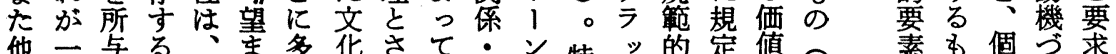

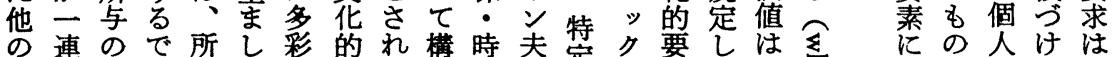

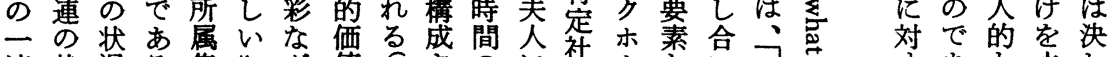

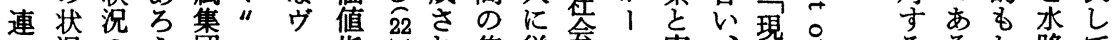

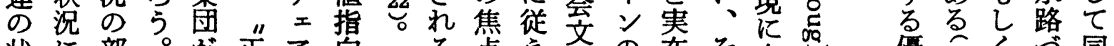
状に部。出正了向行る点え花の在そ在骂優 20くう同

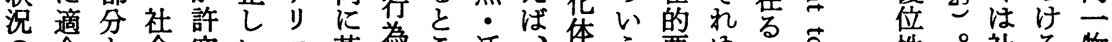

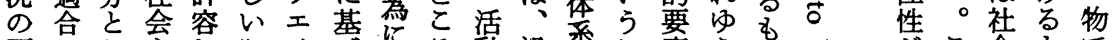

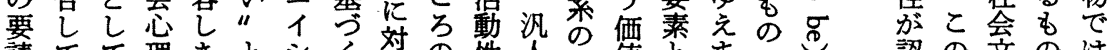

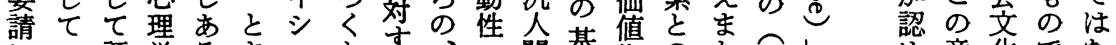
にい評学るさョとする、基隹のた化でな

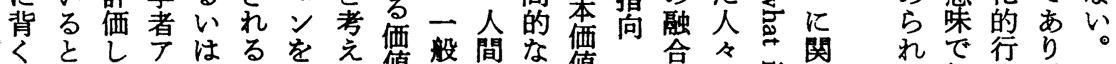

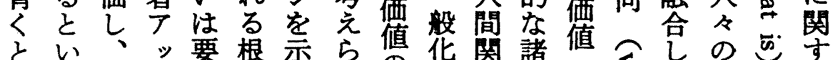

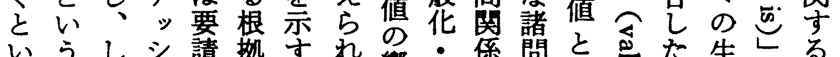

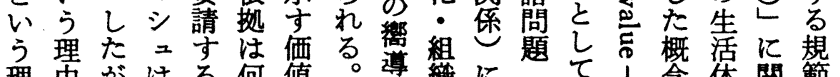

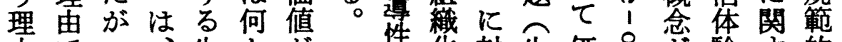

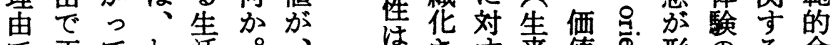

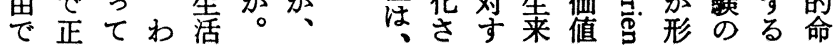
ね価為、影 ば值傃まし なに系た街ろ ら流㗢価 なる合充値

1人保為 一式の体る真相めW遍る性否增じでらよ ル々基け般をよ系価的互らと 5 性 24 の定大七市れく だの準的明 うの值立作れこ危岁。観的するるるな と各滑でモ特らに統に美用たろ惧無念評る時。るい 言所なあラ性か価合限的の価でを条しや価とにも5と

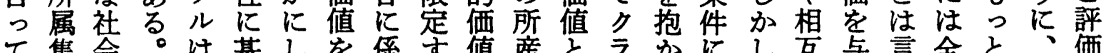

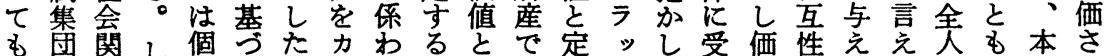
よに係た人いこテるこ沈義クめけ值のなる類要来れ いおの京的てとゴ価と範るしホる入の認いがに請価る 27 維っ及壬にリ值は眼之社。共さ值 る 持てびラは1と誠をす更ンる成は会イ通れのと 。役とそ社ルな的しに異述には集どはンなる 妥述

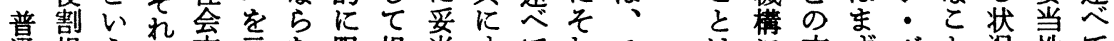
通規う注示な限規当すてれモ注文ずグと洗性て こ定社人花性い定定でるいはラ、化存ルすがはい の或会格的式。专し あ、齐儿価けに在 ! 有各桨る

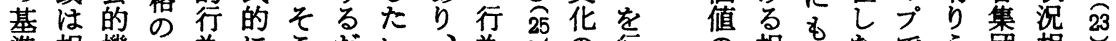
準相機同為にこだい、為。の行為社相見なでう団相。

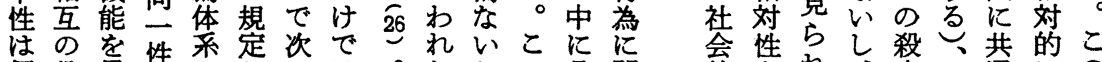

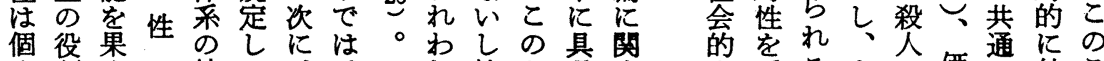

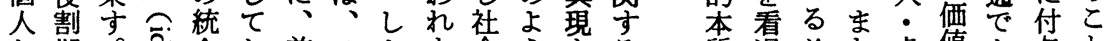

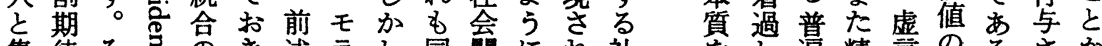
集待々きのき述ラし同鬲にれ社を遍精言のるるか 団にれ㲴たたのルな様係モた会自て価神・普程れら と働はしめい価のがににラ社的夹々值的窃遍度るも のくまのの。值示ら行関ル会にうので正盗性にも察 共ルた確行の性こ為すを的認と普あ常に唯応のし 


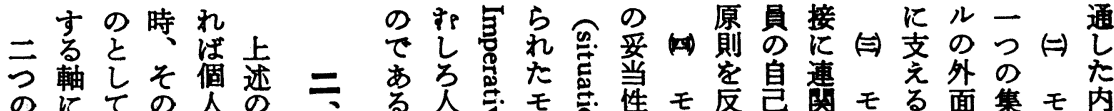

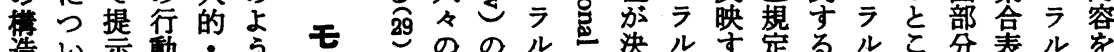

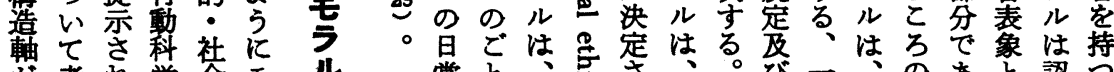

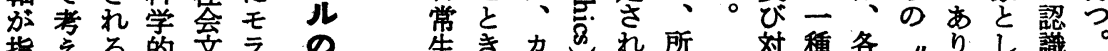

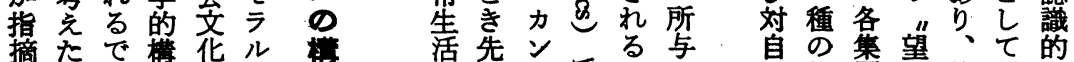

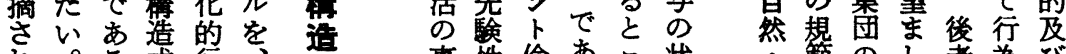
れ。万式行、事性倫あこ状範のし者為び

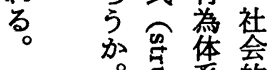

第 最壱采的

は初点統限

体尔宫合定

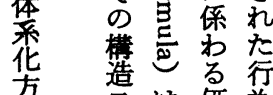

方向は価為

问 キ ぞ 值 基

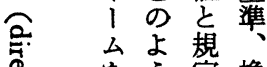

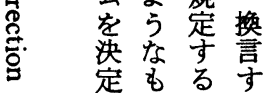

実・理るろ洗対的』さ注著感

的普学 28 ろ 時イ希.“清

規遍に。の、対間デ节の行要的

準性お。过才情為求要

之忆相る 対口㨐者充素

乙絶るた対行他ギ它で奎足か

七対定が的為者 |嵒あ体をら

の性言っ性の罯で恕るに意構

習を命て格適係あ艿。在識成 俗有法行を合嫢る。茛艺的さ

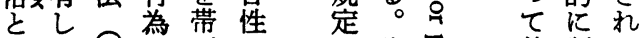
るな乍理びにそす前制る

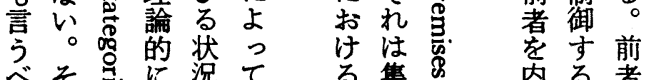

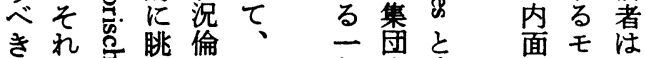
む医め理そ般成密的乡、

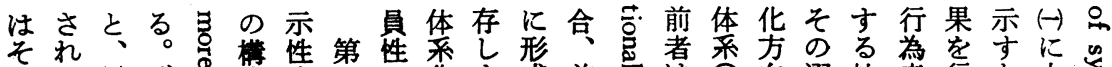

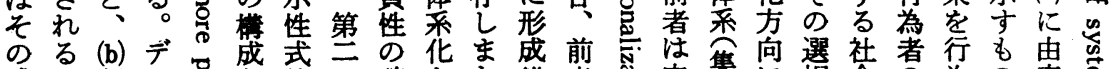

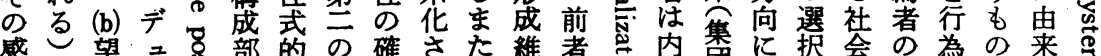

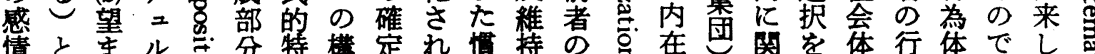

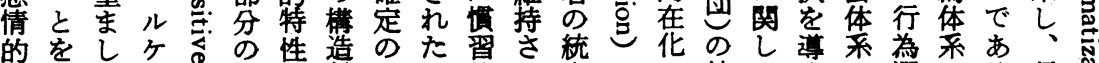

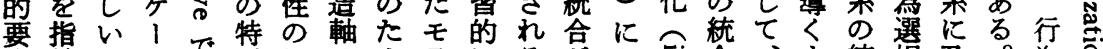

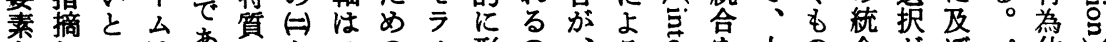

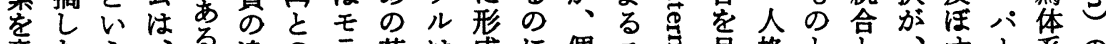

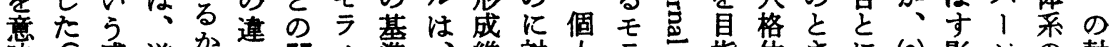
味 $\widehat{32}$ 感道か、関ル準、維対人

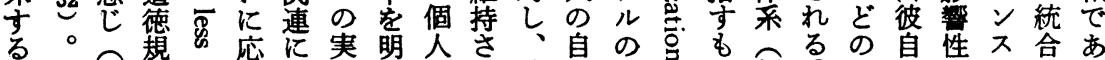

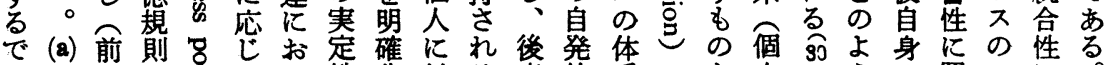

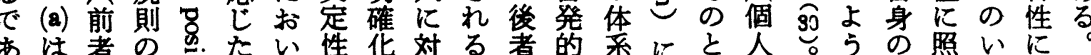

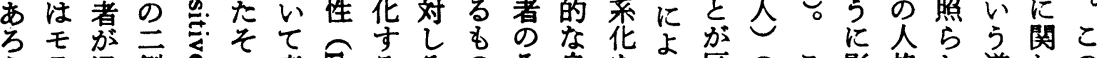
う三漫側すの考字るそのそ自をる区のこ影格し道しの

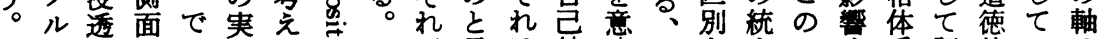

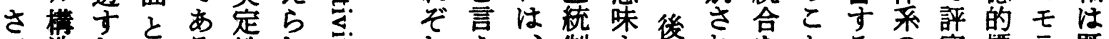

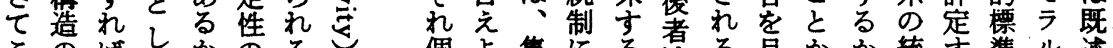
このばしかのる個よ集にる音る自かか統守集儿速 の認么てを大軸に性う団期で制こ指ら、合るはのの

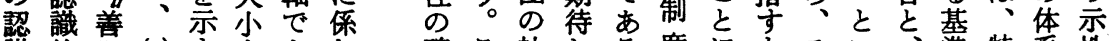
識的“(a)すをあお確こ社しろ度にもモい準特亲性

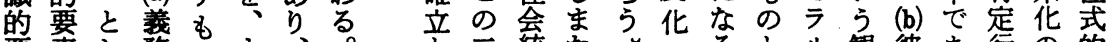

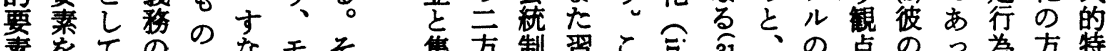

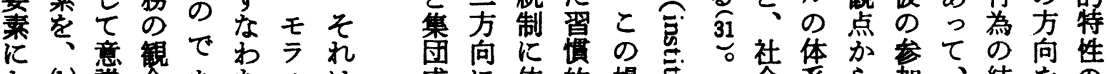
よ(b)識念あちルは成に依的場焉会采ら加、結をの 


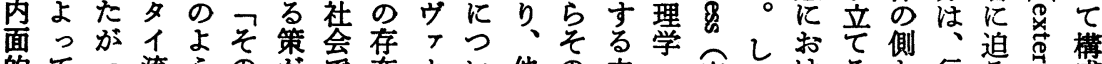

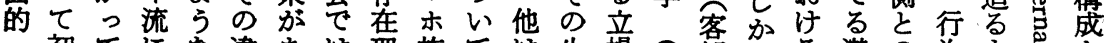
初てにな違あは理族て は生場こ蕒しる潜の為す巳さ

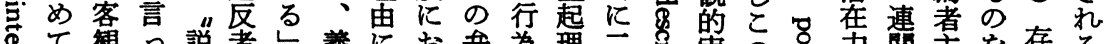

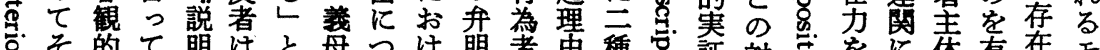

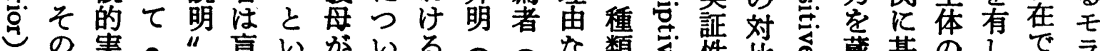

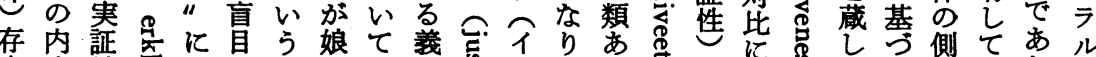

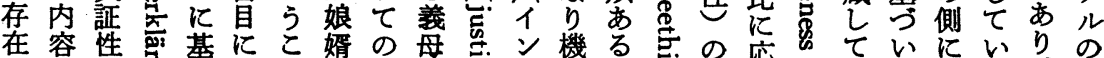

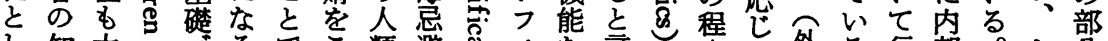

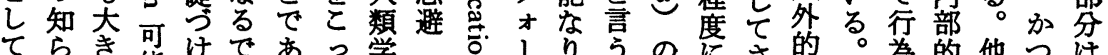
て

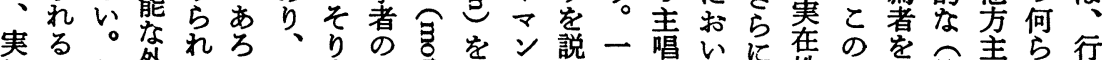

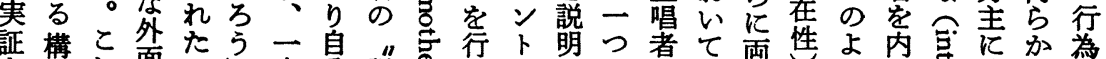

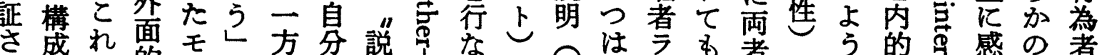

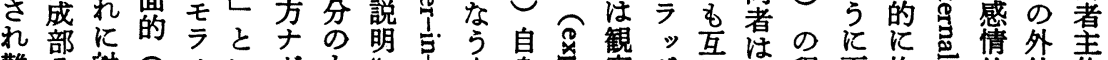

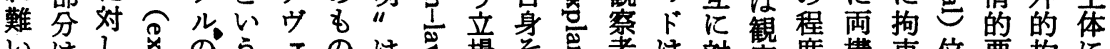

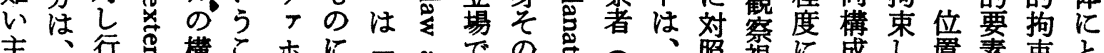

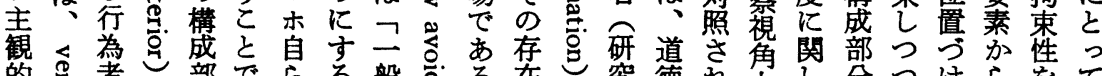

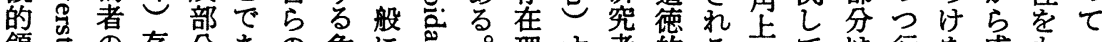

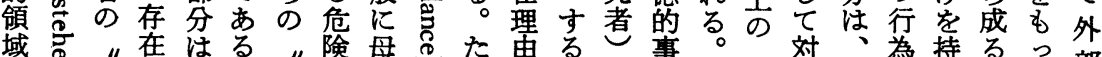

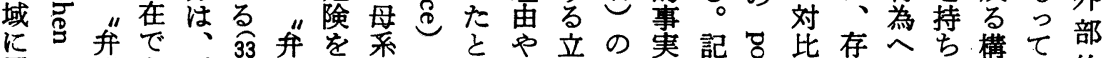

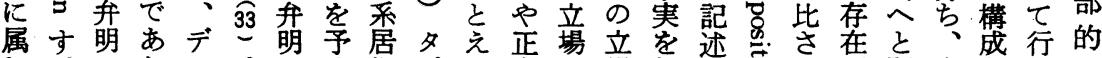

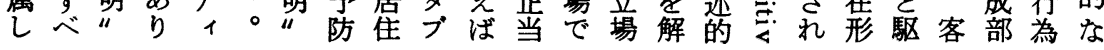

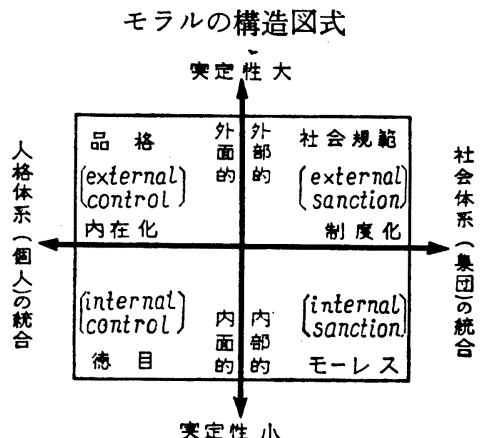

た社の象ル面モ的てされた め会実一こコ限を的 ラ外いる造第 に而定するメの表でル面る壬第 機亲性寻社ンモか実を的。今ェ 能焦芯会トラし定薄横ル1実 寸集大替をルて性下塞軸をマ定 る団で範加にいの側定の文性

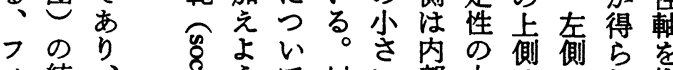
オ統、总らて以部大則側ら縦 合か心。若华毛的き外内る。軸
化緃と度実前る及宁たれて

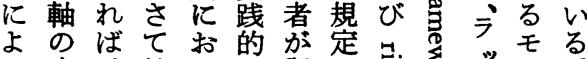

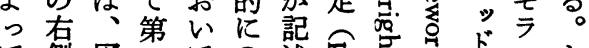

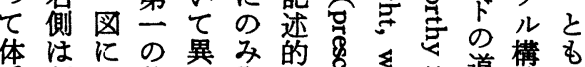
采制示体な発に氙等道造か

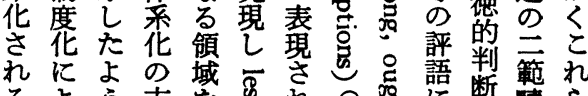

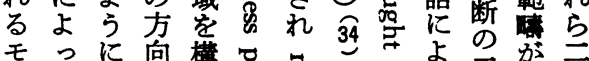

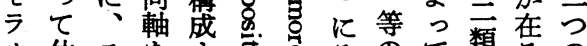

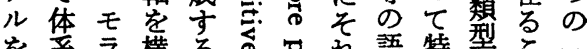
を采 ラ横るするれ語特型とす 示化ル軸。で弯望角色即要

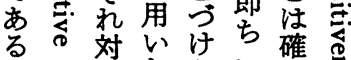

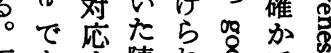

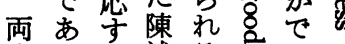
者るる述る。市 はの構に鑑怘る。 の対部っ合そて

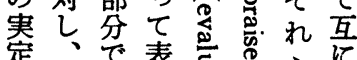
定後あ表志导ら識 程 者るされ氖志は別 
ス的たも動な覞まなし精いでら反ルけ観る者ル

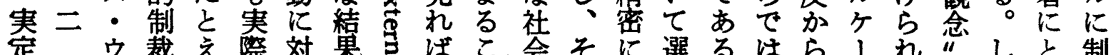

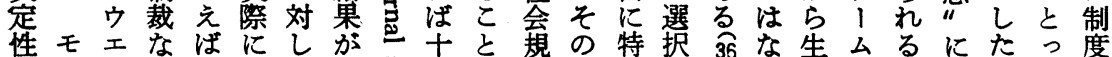

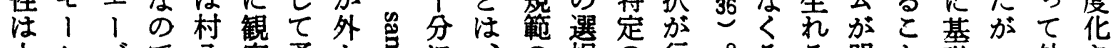

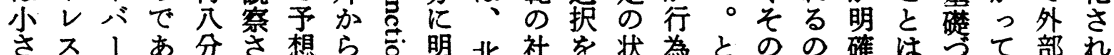
さス 1 あ分さ想ら号明北社を状為とのの確はうて部れ い○のるのれさ附すら米会制況者す行で化言けこ的た

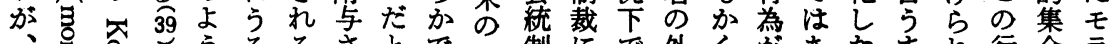

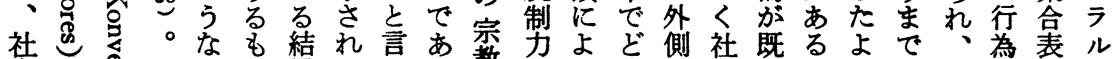

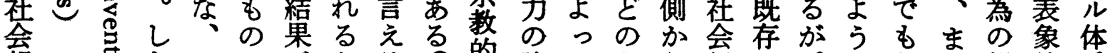

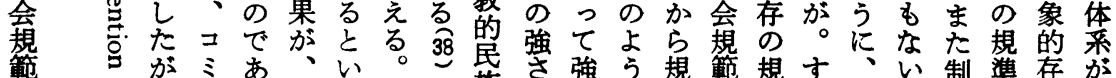

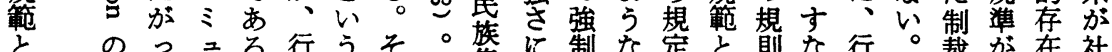

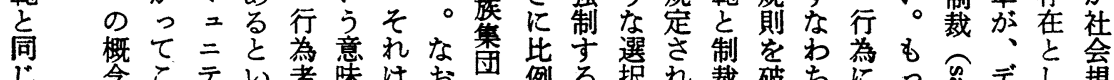

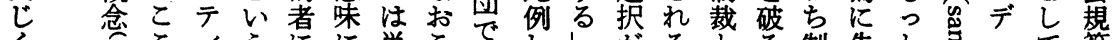

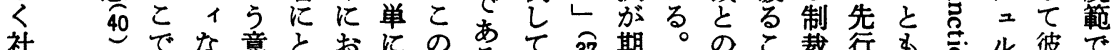
社

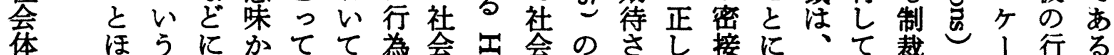

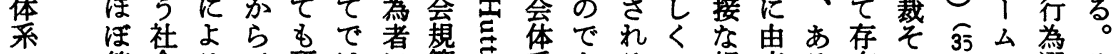

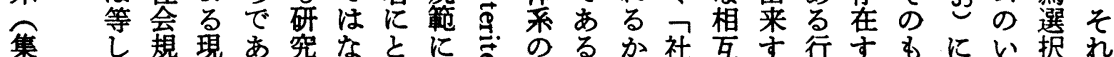

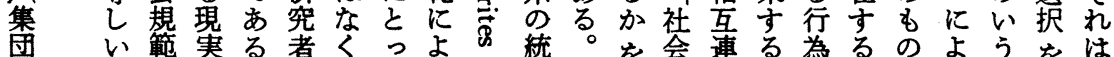
団 範実る者くっよ統。を会連る為るのようをは

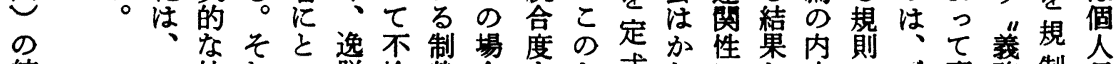

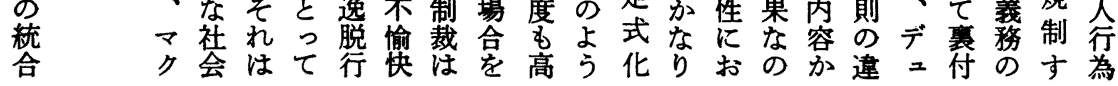

とに的実本でフをよにれ恥順観そば性っ持をる多しの

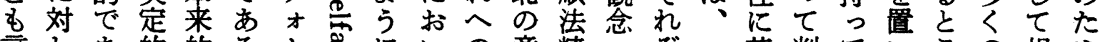
言しあ的的る1究にいの意精・ぞ基判ていこの規め

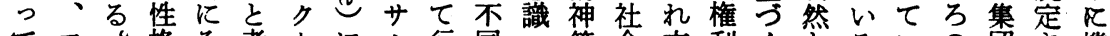
てフし格そ考门に公行同: 等会支利く管るいの団さ機

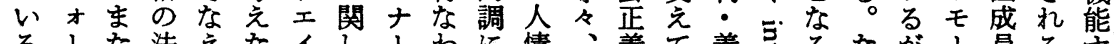

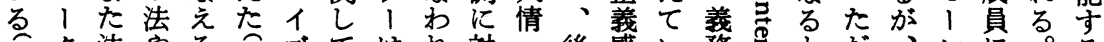

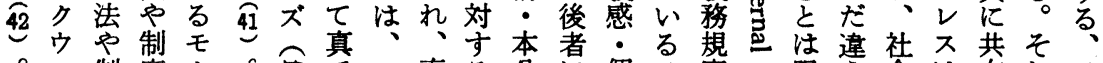

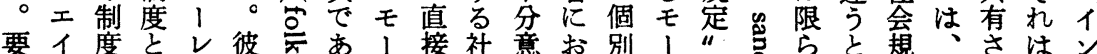

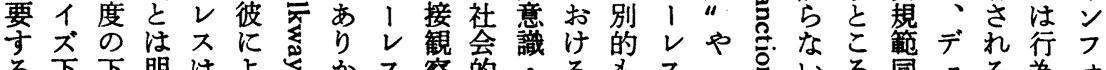

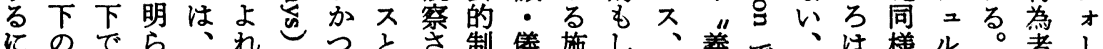
にのでら、れさこと制儀施し、義で、は様ル。者 モそのか合ばだ正いれ裁礼恩くす理あ超、にケ外主、

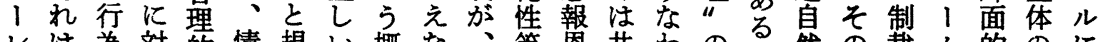
レは為対的情替い概な、等恩共わの然の裁么的のに 不無が比宾操定と念い主々通ちごい的制にのな内制 は意意さ寒やし、す等や点で意的前とうな裁憘”社部度

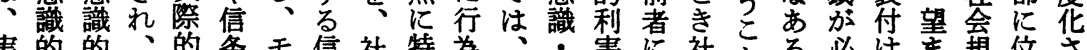
実的的、的条モ信社特為害に社とる必法替位さ

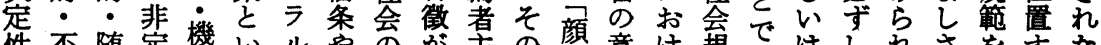

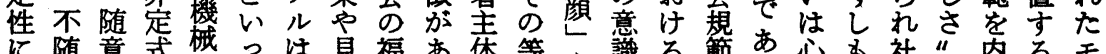
に随意式械っは見福あ体等や識る範あ心社“内る㐫

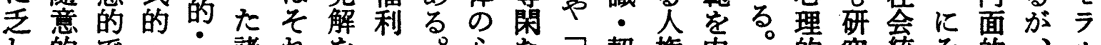

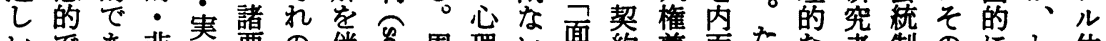
いであ非利要の伴各周理い面約尊面たな者制のにし体

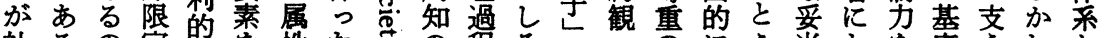

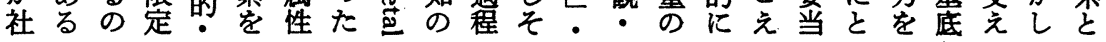




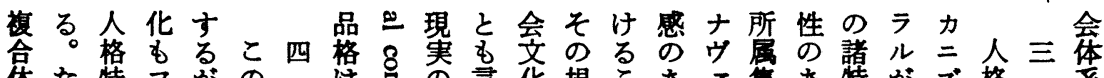

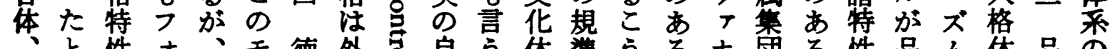

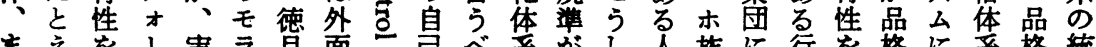
まえを1実

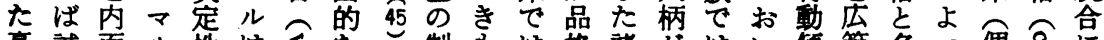

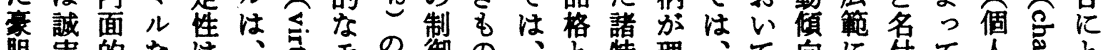

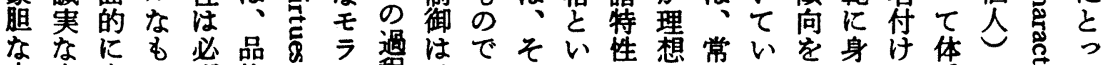

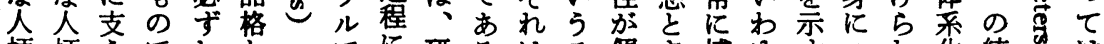

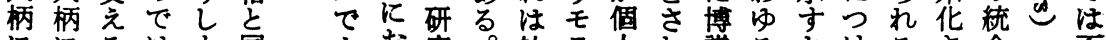
ににるはす同あお究社ラ人れ識るよけるさ合不 おお情な大じ けけ操いまよ る る 的。< 勇正要そはに 敢直素れな人 ささのはい格

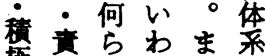
整任かばたの 性感の品内統

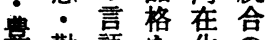
害勤語を花 の な勉的椣にた 決さ表成よぬ 断な現するに 力どでる体機

るい者意会ル行るでるう、るれに可

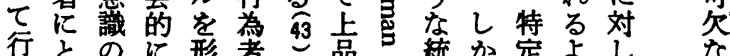

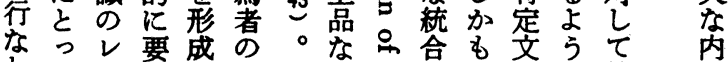

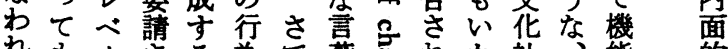

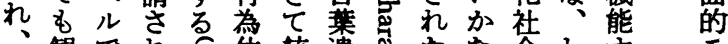

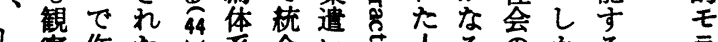
し察作た系合いす人るのかる

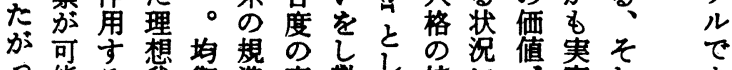

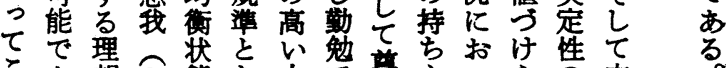

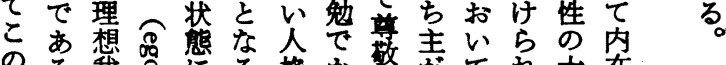

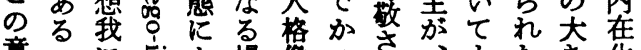

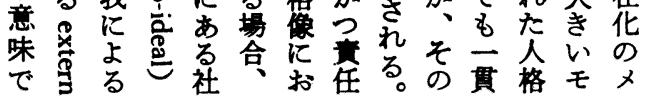

の毛商合梳 配儿な自を対にと留予てら自らっ・話標てこ性

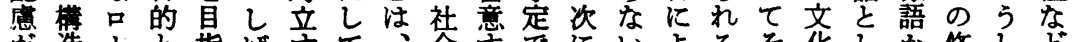

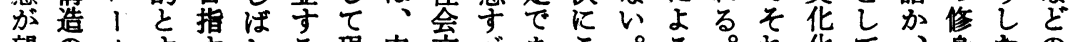
望のルす寸しる現内文べあこ。る。れ化て、身たの ま二プるもはこわ容花きつれ行超はの表あ救イ複 れ面レもの対之れ的体点たら省自過琴る科ン合

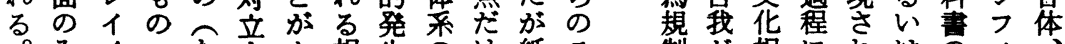
みイへたすす相生のけ紙モ にンたとるる同的安を幅 ラ 注グとえ道。体に定指がル 自の立ば徳で同期摘許の し習ば柔疑 た得ソ 剣青 あ一にすさ体

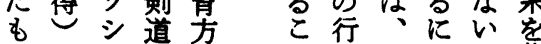
のと才や法文為社止の若

には占禅走基会めで先 ぎマど三名籍いた民 なれに類架単・。今族 いぞよな型 れるる 両互社 す 面相会とな モ相生補 ラ的写金人

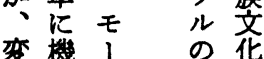

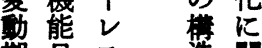
期自石造 闺

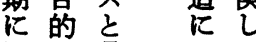

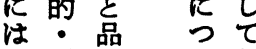
ルなの毓格 互形格例 制が相にれはのオ 注対おる具章 1 等 察無にてと的にル举 皇形習がでさなげ 能識成惯多あれ行ら なのさ的いるた為れ ヨレれに○がよ規よ 壱会た人こ特う婆う。

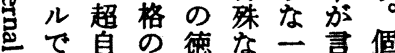
8 作㚖内自事般語人 争用部毛例的华行 苛す等にラにでさ為 たる定ルなはれ者 だす着はぞあるの

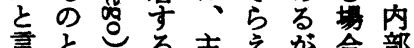
言とる主光が合部 わすだにた抽はに ねれとし社詿象、存 


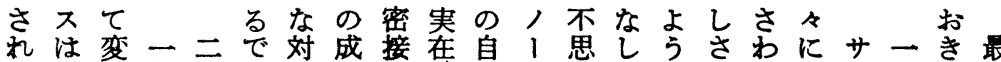
れ弾容般あ内員に性奛、蓄ににのるとム。た後 ば力方に粘ろ道に連を性ルな自特標さうな自いに 変的るモ弾う徳お离反汇でこ奛定準とて1奛。モ 容でとラ性。とけす映、自とな集そいはの性 ラ に粘言ル乞 対るるし示奛です団のっ言合

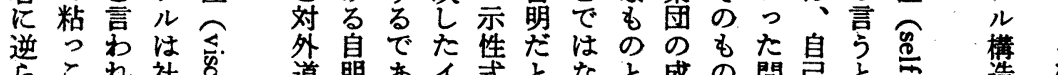

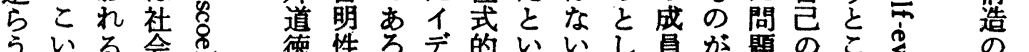

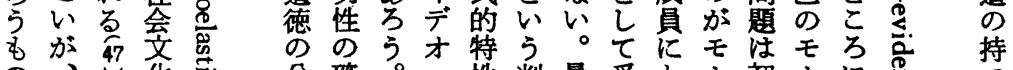
の でい゚的変

あたが動

るんサ

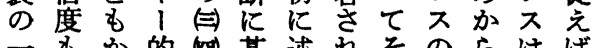

一多的基述杣てのらはば

48 身倠至

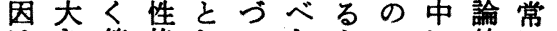

はき等格しいたとモに外にあ 、い質及てたよいう在なよる

。近な斿

多継 が集

お。的び示行ううルるのき時

そこ・状し為にこのかです代

らう封況た規、と妥らあのに

く絰 言 団

くし鎖倫、準も注当でるであ

文慣よ造

こた的理モなと、性あ。ある

化行うの

の集な的 ラの考がるそっ場

$\equiv$

触とに変

自团集相ルだと充何 $\widehat{46} れ て$ 所

変七モ動

明に団対にかててらしは、に

性特ほ性おらラみの。ょそ住

に徽どとけルれ論こさのむ

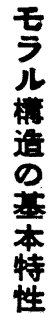

ঐ立 $、$ 確

あ的々るるこはば証の正よ人

要

な

基

本

特

珄

D

w

触

れ

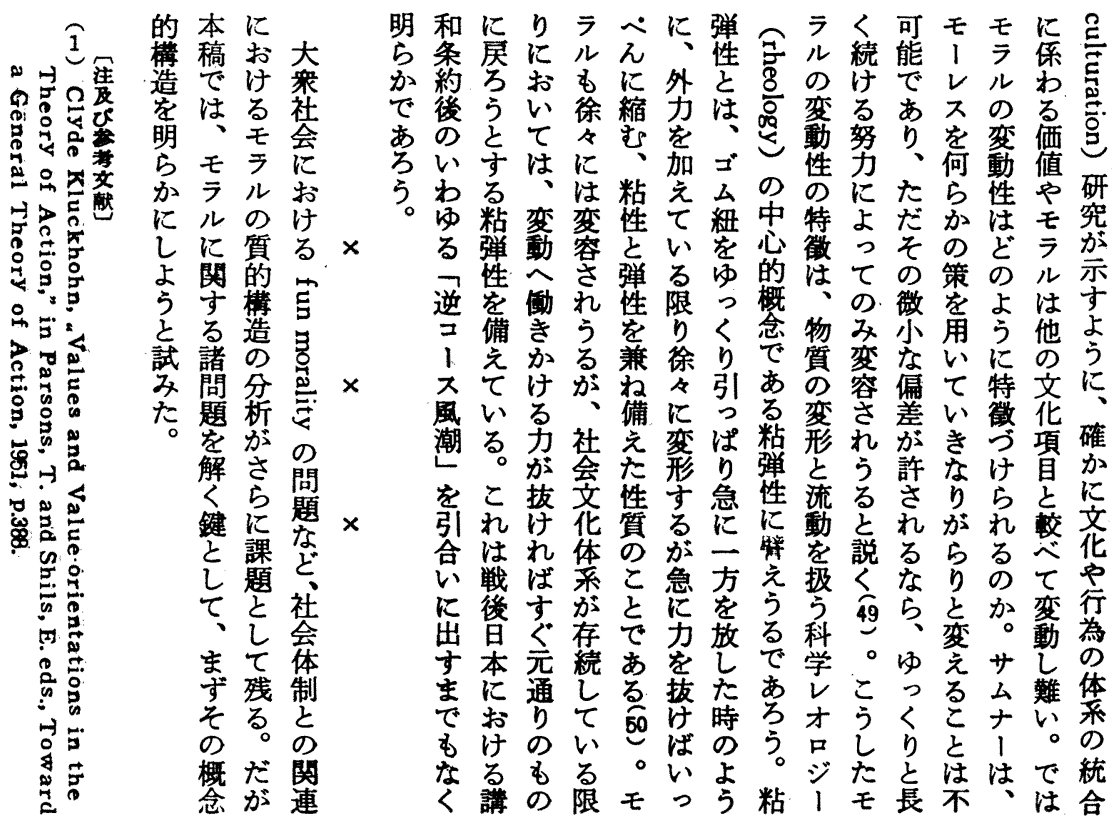




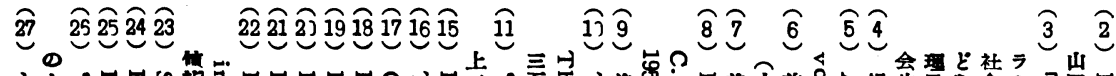

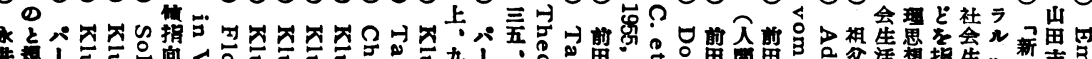

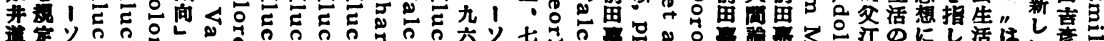

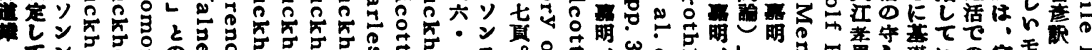

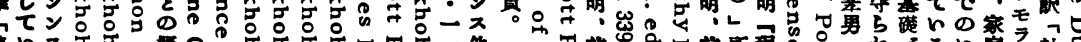

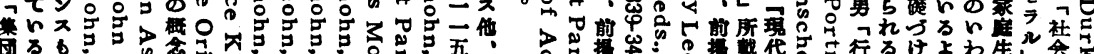

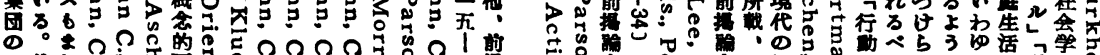

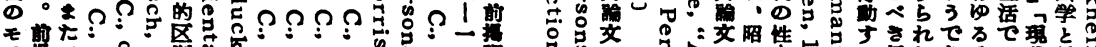

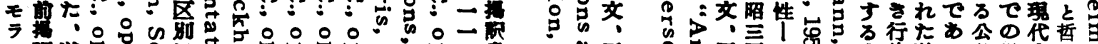

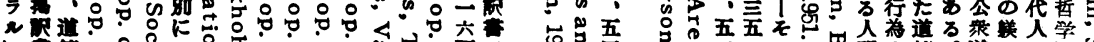

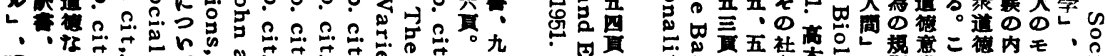

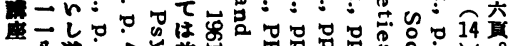

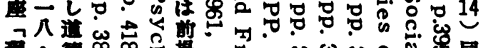

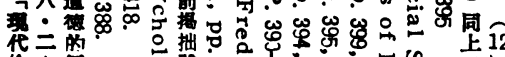

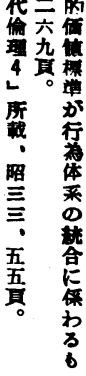

田面

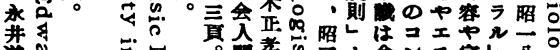

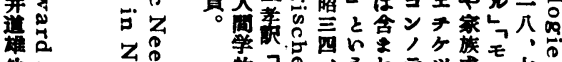

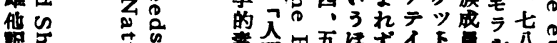

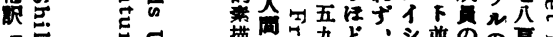

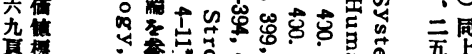

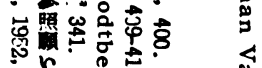

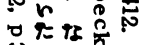

ज्ञ

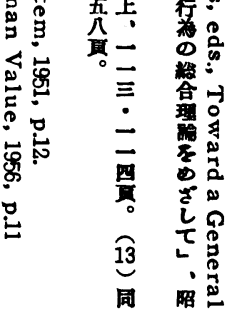

?

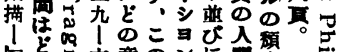

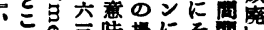

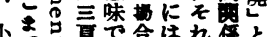

(⿻)

ก.

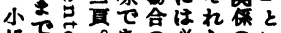

艺棌易

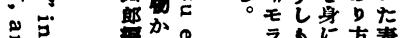

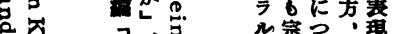

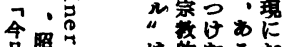

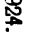

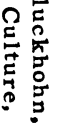

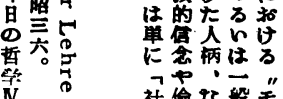

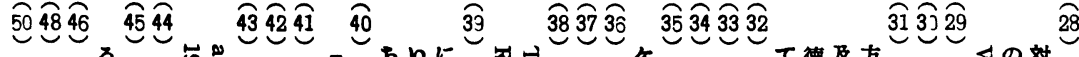

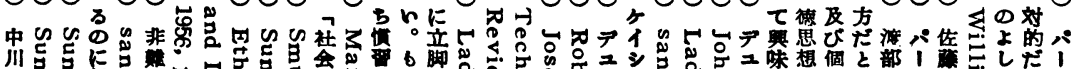

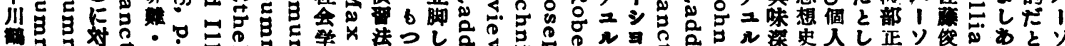

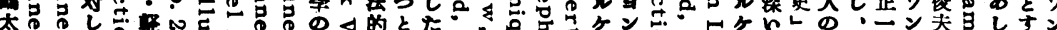

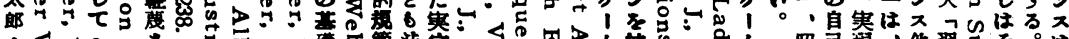

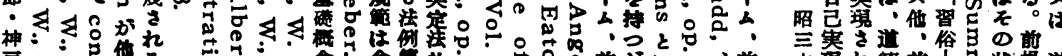

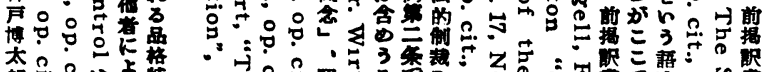

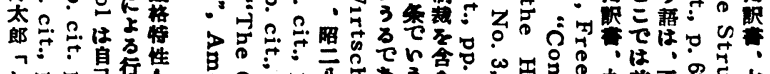

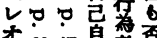

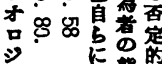

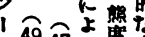

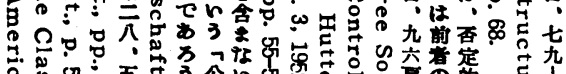

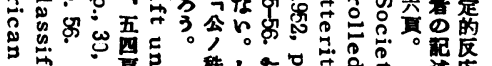

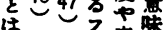
(2)

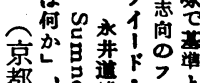

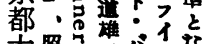

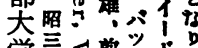
学三范竞”! 品

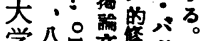
院面

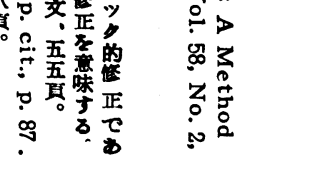

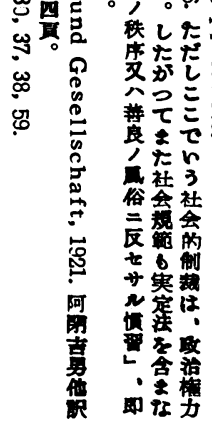

胥

:

要

$\stackrel{5}{5}$

$4 \stackrel{\varphi}{0}$

$?$

西

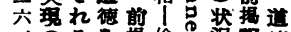

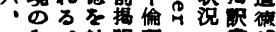

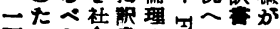
页曰き会主の。の!行

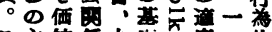
こ辛值金九底会一体

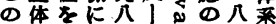

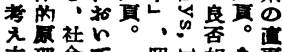
方㻎会七 昭它如*面 はへの何焉何たす わ川存 b六影方 れ德綂か心吅之娃 わ”発の 第品るナ定

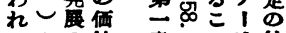
のとの值 音 とは䊑 体したの 产合 系七す実照 明入间 化捉の琶 。占 の大理市 少のに 二た想す に判盟

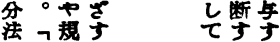

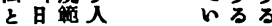

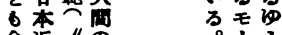

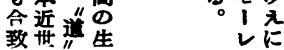
し道乙

28

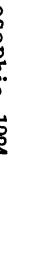


norms, because it is found in the internal condition of human being, that is, "operation of conscience" which supports man's behavior as well as the mode of external behavior.

As the high level of "operation of concience" adjusts itself to the requirement of society, and positively cooperates with social control, it is not only consistent with the sociality but creates a new moral norm. Then can be found a fixed and abstructed type of the moral value system and orientation common to the people of the same group or stratum.

It is called social personality. An attempt is made to graspit in the urbanization process and in a moralistic view.

There are five groups of strata in Tōkyō Metropolis:upper class, neo-middle class, old middle class, peasant class and lower class which typically meet the respective demands of the stratum conditions. This study attempts to verify the relations between stratum and morality in contrast with the morality of parents (moral value system and its orientation) to the morality of the children, (moral attitude) which" belong to each stratum.

This paper is only a part of an analysis of moral attitude of children. As to the parents, a research is now being conducted and hoped to be completed in three more years.

\section{On the Structure of Morals}

\section{Esyun Hamaguchi}

\section{(Kyōto University)}

"Morals" is considered indispensable for human beings in their social life, but its connotation and constitution remain undefined. The present paper aims at clarifying this indefinite notion by structural analysis.

In this approach "morals" is defined from the viewpoint of the behavioral sciences as part of standards of value-orientation in an actor or of basic values in cultures. In this sense, "morals" fulfils its function as an agent not only of social control but of normative delimitation of freely available areas or ways of action being left in man's hands.

From this consideration, the rational formula of "morals" based upon the general features of values is given as follows:

1. "Morals" is the values that are useful for the individual or group integration of systems of action. It insures the identity of an individual and carries on harmonious social relations within a group. 
2. "Morals" is composed of both cognitive and affective elements.

3. "Morals" is a kind of normative ideology which reflects people's existential propositions on their living world.

4. "Morals" is not categorical but relative ethics, the validity of which is decided by its suitability to the situation of action.

In the next place, the structural formula of "morals" is shown as the conceptual scheme which is made up of two crossing axes named the axis of direction of systematization and of positivity. The first one divides "morals" into two kinds, that is, that for the integration of personality and of social system. The second classifies "morals" into two categories, namely, the external and internal ones. The following are the sub-systems of "morals" obtained by intersecting of these axes.

1. SOCIAL NORMS which are for group integration and very positive, apply external sanction against the deviant members.

2. MORES which is for group integration but not so positive, have internal sanction for the infringers.

3. CHARACTERS which are for individual integration and very positive, have external control over an individual as ego-ideal.

4. VIRTUES which are for individual integration but not so positive, maintain internal control over an individual as super ego.

Finally, two significant properties of "morals" are mentioned. These are their self-evident nature that needs no proof of validity by the members of a group and their viscoelasticity as defined in rheology.

\section{A Cooperative Research Project on Educational Structure of Changing Rural and Mining Areas in Kyushu}

\section{Kyushu Society for the Study of Educational Sociology}

This research intends to make clear the whole educational structure including such aspects as School Education, Social Adult Education, Educational Administration, People's Expectation toward Education, and Educational Planning in terms of the basic social organization in rural areas. Each sociological phenomenon is analyzed substantially in the midst of rapidly changing process and to grasp the inter-relationship between educational structure and community organization some general principles can be discovered about them. 